\title{
Vellaria solenta (Monothalamea: Allogromiidae) \\ - new species of soft-walled foraminifera from Sivash Bay (the Sea of Azov)
}

\author{
N.G. Sergeeva ${ }^{1}$, O.V. Anikeeva \\ A.O. Kovalevsky Institute of Biology of the Southern Seas, Russian Academy of Sciences, Nakhimov \\ Ave., 2, Sevastopol, Crimea, 299011, Russia.E-mail: oksana.anikeeva@gmail.com \\ ${ }^{1}$ Corresponding author.E-mail: nserg05@mail.ru
}

ABSTRACT: We describe Vellaria solenta sp.n., a new species of soft-walled, monothalamous foraminifera based on 16 individuals found in the hypersaline Sivash Bay (Sea of Azov). The distinctive morphological features of the species are the presence of protoplasm completely filling the entire space of the test and the interior of the apertural neck, and the short, thin processes that extend beyond the aperture in most individuals. Other representatives of the genus Vellaria, namely V. pellucida Gooday et Fernando, 1992 and $V$. sacculus Gooday et Fernando, 1992, were found in the south-western of the Sea of Azov (Sergeeva, 2016), where the salinity did not exceed 14\%, compared to 74\%o in Sivash in the case of Vellaria solenta sp.n.

How to site this article: Sergeeva N.G., Anikeeva O.V. 2021. Vellaria solenta (Monothalamea: Allogromiidae) — new species of soft-walled foraminifera from Sivash Bay (the Sea of Azov) // Invert. Zool. Vol.18. No.2. P.152-158. doi: 10.15298/invertzool.18.2.06

KEY WORDS: Soft-walled foraminifera, Sivash, the Sea of Azov, Vellaria solenta.

\section{Vellaria solenta (Monothalamea: Allogromiidae) - новый вид мягкораковинных фораминифер из залива Сиваш (Азовское море)}

\section{Н.Г. Сергеева ${ }^{1}$, О.В. Аникеева}

Институт биологии южных морей им. А.О. Ковалевского РАН, проспект Нахимова, 2, Севастополь, Крым 299011, Россия. E-mail: oksana.anikeeva@gmail.com

${ }^{1}$ Автор для переписки. E-mail: nserg05@mail.ru

РЕЗЮМЕ: Описан новый вид мягкораковинных фораминифер Vellaria solenta sp.n., основываясь на изучении 16 особей, обнаруженных в гиперсолёном заливе Сиваш (Азовское море). Отличительными морфологическими признаками вида являются полностью заполненное протоплазмой пространство клетки и апертурной шейки, а также ветвистые, короткие, тонкие отростки, выходящие за пределы апертуры у большинства особей. Ранее в юго-западной части Азовского моря были обнаружены и другие представители рода Vellaria - V. pellucida Gooday et Fernando, 1992 и V. sacculus Gooday et Fernando, 1992 (Сергеева, 2016), однако солёность в местах их обитания не превышала 14\%о, в то время как солёность в Сиваше, при которой обнаружен вид Vellaria solenta, составляет 74\%. 
Как цитировать эту статью: Sergeeva N.G., Anikeeva O.V. 2021. Vellaria solenta (Monothalamea: Allogromiidae) - new species of soft-walled foraminifera from Sivash Bay (the Sea of Azov) // Invert. Zool. Vol.18. No.2. P.152-158. doi: 10.15298/invertzool. 18.2.06

КЛЮЧЕВЫЕ СЛОВА: Мягкораковинные фораминиферы, Сиваш, Азовское море, Vellaria solenta.

\section{Introduction}

Sivash Bay, or Rotten Sea, is a shallow lagoon-type bay in the western part of the Sea of Azov, separating the Crimean Peninsula from the mainland. It is shallow along its whole extent, $0.6-1.5 \mathrm{~m}$ on average but reaching a depth of $3 \mathrm{~m}$ in a few places. In summer, the water temperature varies from 20 to $32{ }^{\circ} \mathrm{C}$ and this heating leads to strong evaporation and high mineralization.

The bay extends for $115 \mathrm{~km}$ from north to south, and $160 \mathrm{~km}$ from west to east. In the eastern part, it is separated from the Sea of Azov by a long narrow sand-and-shell spit, Arabatskaya strelka (length $115 \mathrm{~km}$, width from $270 \mathrm{~m}$ to $7.5 \mathrm{~km}$ ). Sivash also connected with the Sea of Azov through two narrow straits, 150-200 m wide, near Genichesk (Genichesky Bay), while the narrow (8-12 km) Perekop Isthmus separates Sivash from the Black Sea in the west. The area of the bay amounts to about $2,560 \mathrm{~km}^{2}$, of which about $100 \mathrm{~km}^{2}$ are occupied by islands and $560 \mathrm{~km}^{2}$ are covered by water intermittently only (Report of the Collegium No. 2, 2015).

Sivash Bay is a unique ecosystem that doesn't have an analogue anywhere in the world. The salinity varies from the north to south, within the range 22.0 to $87.0 \%$. The bottom of is covered with a layer of silt with a mass of rotting algae and a strong hydrogen sulfide smell.

Sivash Bay is the most anthropogenically and technogenically impacted area of the coastal zone off Crimea and is characterized by specific hydrodynamic and hydrochemical processes (Sovga et al., 2018a, b). From the first half of the 20th century to the present, it has been subjected to serious anthropogenic impacts twice. The bay was a hypersaline lagoon before
1963 (average salinity of $141.0 \%$ ). At this time, the North Crimean Canal was built to improve water supply to the Crimean Peninsula by diverting the waters of the Dnieper River. The subsequent development of irrigated agriculture resulted in effluent waters from the fields draining into Sivash Bay and the salinity therefore began to decrease. In 1997 it had dropped to $17.0 \%$. These events caused a reorganization of the entire ecosystem due to drastic changes in salinity, transforming a hypersaline basin into a brackish-water one. A fundamentally new brackish water ecosystem gradually formed in Sivash Bay. In April 2014, Ukraine made a political decision to stop supplying Dnieper water via the North Crimean Canal. Discharge of fresh water to the bay almost ceased. Salinity began to increase, and the Sivash ecosystem underwent another transformation (Shadrin et $a l, 2018)$. At present, Sivash is acquiring hypersaline properties again. Studies of thermohaline conditions in the bay have shown that the salinity has recently increased to 60.0 $80.0 \%$, i.e., almost 3- to 4-fold since 1997 (Shchurova et al., 2016).

Recent studies have shown how benthic communities in Sivash Bay have responded to these environmental shifts. The taxonomic structure of the community has changed. The diversity of major macro- and meiobenthic taxa has decreased slightly, with some groups disappearing completely. However, the species diversity of some meiobenthic taxa, such as Harpacticoida, has increased (Shadrin et al., 2016) and organisms that were previously unknown in this region have been discovered (Sergeeva, 2016; Shadrin et al., 2016, 2018, 2019; Sergeeva et al., 2019, 2020).

In this paper we describe Vellaria solenta sp.n., a hitherto unrecorded representative of 


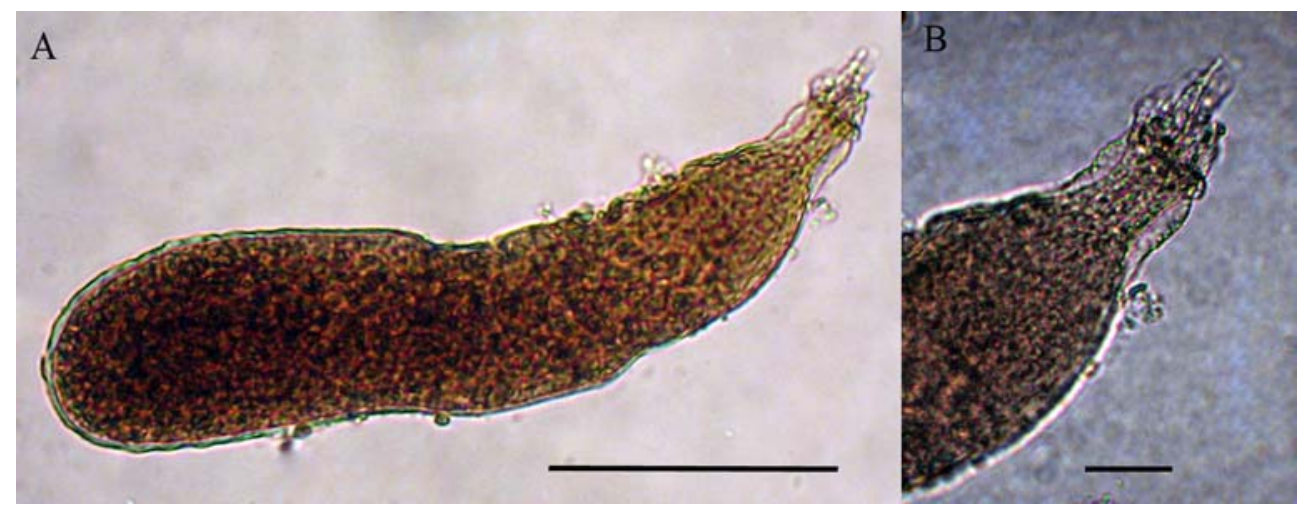

Fig. 1. Vellaria solenta, the holotype: A — general view of the specimen; B — aperture part. Scale bars: A $100 \mu \mathrm{m} ; \mathrm{B}-20 \mu \mathrm{m}$.

Рис. 1. Vellaria solenta, голотип: А - общий вид экземпляра, В - апертурная часть. Масштаб: А 100 мкм, B - 20 мкм.

the fauna of soft-walled monothalamous foraminifera (Protozoa) in the hypersaline Sivash Bay.

\section{Material and methods}

This work is based on a collection of softwalled foraminifers found in samples of bottom sediments obtained on July 17, 2020, during a study of the bottom fauna of Sivash Bay. The sediments were sampled using a plastic beaker with a volume of $23.75 \mathrm{~cm}^{2}$ and fixed with $4 \%$ formalin solution.

In the IBSS laboratory, the sample was carefully washed with water through sieves with a mesh size of 1 and $0.63 \mathrm{~mm}$, and the residue concentrated on the lower sieve was stained with Bengal Rose. The stained sample was placed in a Bogorov chamber and meiofaunal organisms picked out under a MBS-9 binocular microscope. Specimens were sorted into major meiofaunal taxa and counted. Foraminiferal specimens were studied further using Canon and Mikmed-6 microscopes and photographed using a Canon A620 digital camera.

The holotype and three paratypes of Vellaria solenta are deposited in the collection of softwalled foraminifera of the A.O. Kovalevsky Institute of Biology of the Southern Seas, Russian Academy of Sciences.
In this work, we follow the classification of soft-walled foraminifera according to the WoRMS (Hayward et al., 2021).

\section{Results}

Supergroup Rhizaria Cavalier-Smith, 2002

Phylum Foraminifera d'Orbigny, 1826

Class Monothalamea Haeckel, 1862 (sensu

Pawlowski et al., 2013)

Order Allogromiida Loeblich et Tappan, 1961

Family Allogromiidae Rhumbler, 1904

Genus Vellaria Gooday et Fernando, 1992

\section{Vellaria solenta sp.n.}

Figs 1-3.

ETYMOLOGY: Latin "solent" meaning hypersaline.

MATERIAL. The holotype (Meib. $71 \mathrm{Al}$. h.) (Fig. 1), three paratypes (Meib. 72 Al. p.1, Meib. 73 Al. p.2 and Meib. 74 Al. p.3) (Fig. 2) and other studied specimens (Fig. 3) were collected in July 2020 in the Sivash Bay of the Sea of Azov $\left(45^{\circ} 52^{\prime} 38.8^{\prime \prime} \mathrm{N}\right.$; $\left.34^{\circ} 44^{\prime} 33.3^{\prime \prime} \mathrm{E}\right)$, at a depth of 5 to $10 \mathrm{~cm}$, in muddy sediment with a hydrogen sulfide smell. All specimens are preserved on the glass slides in gelatin-glycerine. Table 1 contains the quantitative parameters of all studied specimens of Vellaria solenta. 


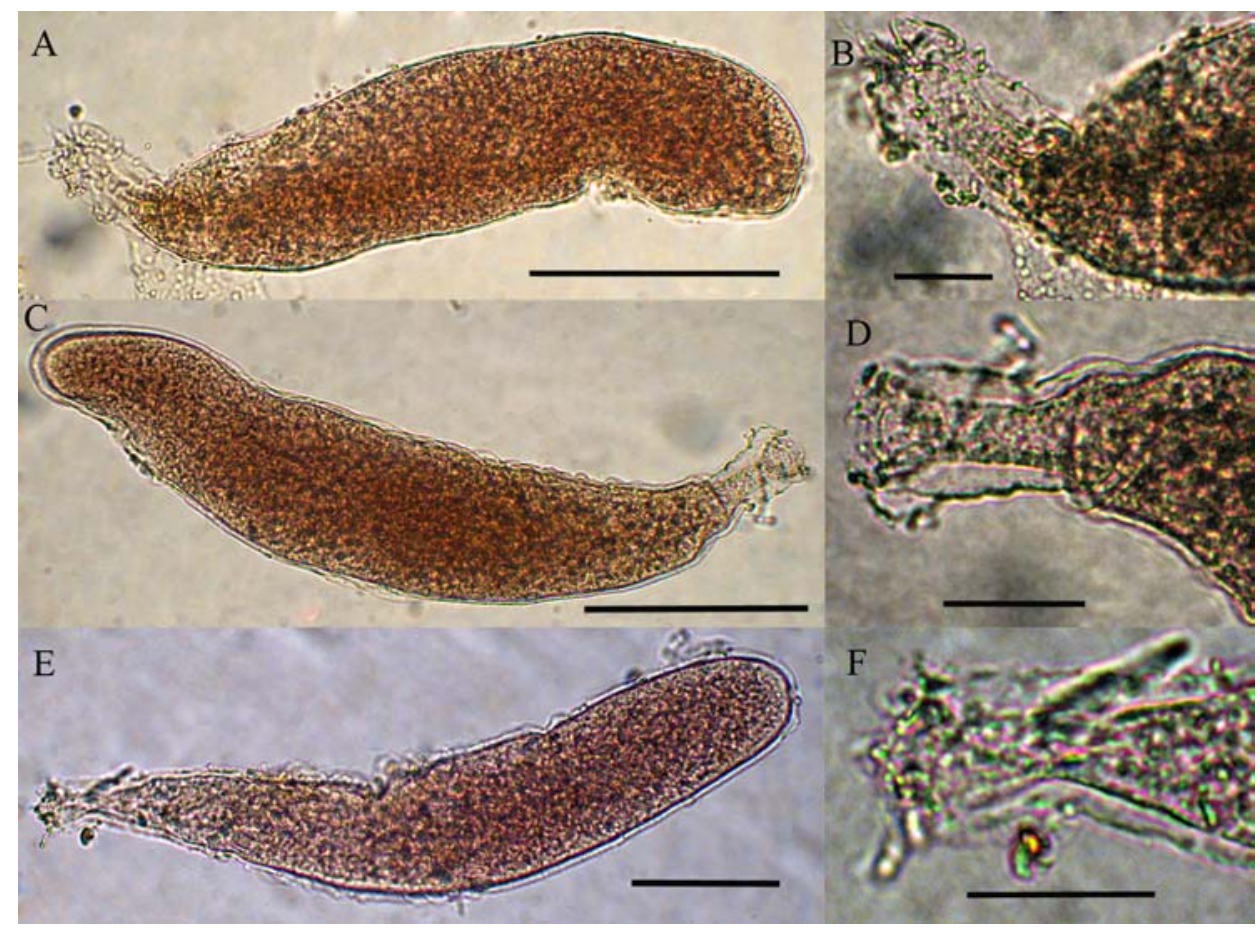

Fig. 2. Vellaria solenta, the paratypes: A, C, E - general view of the paratypes 1, 2 and 3; B, D and F apertural part of paratypes 1, 2 and 3. Scale bars: A, C $-100 \mu \mathrm{m}$; E $-50 \mu \mathrm{m}$; B, D, F $-20 \mu \mathrm{m}$.

Рис. 2. Vellaria solenta, паратипы: А, C, Е - общий вид паратипов 1,2 и 3; В, D и F - апертурная часть паратипов 1,2 и 3. Масштаб: A, C -100 мкм, E - 50 мкм, B, D, F - 20 мкм.

DESCRIPTION: The test is elongated, organic, with a thin, flexible wall. It measures 240-435 $\mu \mathrm{m}$ long and 50-90 $\mu \mathrm{m}$ wide. The protoplasm is homogeneous, fine-grained and contains diatom frustules in some individuals. The nucleus is located in the distal part of the cell; it has a diameter of about $15-28 \mu \mathrm{m}$, but is not visible in some specimens. The only aperture is located at the end of the elongated neck, situated at the narrower end of the test. The form of the apertural neck varies from funnel-shaped with a slightly ragged edge, as in typical representatives of the genus Vellaria, to cylindrical, sometimes becoming narrower at the end. A characteristic feature of the species is that the dense protoplasm completely fills the body space and the apertural neck, adhering tightly to the test wall with no intervening space. In many individuals, the neck has short, thin processes that extend beyond the aperture. The diameter of the aperture in the studied specimens ranges from 18 to $26 \mu \mathrm{m}$. The proximal end of the test is smoothly rounded in most specimens. The coefficient $\mathrm{C}$ (length/width ratio) varies from 3.4 to 7 ; on average it is about 5 .

HABITAT. The new species was found in the Sivash Bay of the Sea of Azov at a depth of 5 to $10 \mathrm{~cm}$, in muddy sediment with a hydrogen sulphide smell. The density was 67 specimens/ $10 \mathrm{~cm}^{2}$. The salinity was $74 \%$. It can be assumed that they actively feed on filamentous, matcreating algae. In some individuals, the filaments of blue-green algae occupied the entire length of the aperture neck and penetrated deeper into the cell.

DIFFERENTIAL DIAGNOSIS: Three valid species belonging to the genus Vellaria are currently known: $V$. pellucida Gooday et Fernando, 1992, V. sacculus Gooday et Fernando, 1992 and V. zucchellii Sabbatini, Pawlowski, 


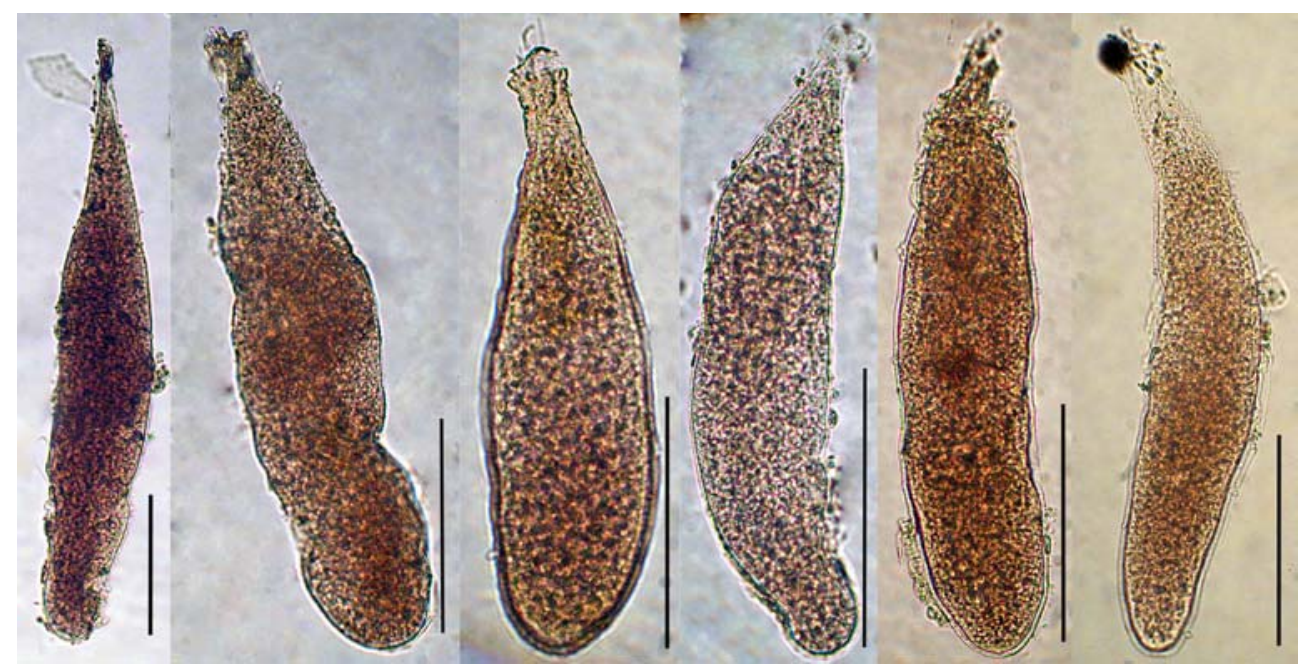

Fig. 3. Other investigated specimens of Vellaria solenta. Scale bars: $100 \mu \mathrm{m}$.

Рис. 3. Другие исследованные экземпляры Vellaria solenta. Масштаб: 100 мкм.

Gooday et Bowser, 2004. The first two species, first described from the Vellar estuary in SW India (Gooday, Fernando, 1992), occur in both the Black Sea (Sergeeva, Anikeeva, 2004; Anikeeva, 2007; Gooday et al., 2011; Anikeeva, Gooday, 2016) and the Sea of Azov (Sergeeva, 2016) quite frequently. The morphological similarity between the new species and the two Indian species is in the structure of the apertural neck and test wall. The test of $V$. solenta is slightly more elongated than that of $V$. pellucida and $V$. sacculus. A distinctive feature of the new species is that the entire space of the test and apertural neck is completely filled with protoplasm. Also, the short, thin filaments that extend beyond the aperture in most individuals have not been observed in other species of the genus.

Vellaria solenta resembles the Antarctic species $V$. zucchellii (Sabbatini et al., 2004) in the elongated shape of the test but new species differs in body size, apertural structure and distribution of protoplasm within the test.

\section{Discussion}

Over 50 zoobenthic species, including accidental introductions, have been recorded during more than a century of research in Sivash Bay. However, most studies have been limited to assessing benthic organisms as a food source for fish and birds (Dovgal, 2005). Soft-walled foraminifera have not been previously recorded in the bay.

Allogromiids were first discovered in 2013 and 2015 in areas of Sivash characterized by different salinities (Sergeeva, 2016; Sergeeva, Anikeeva, 2018). According to our current data, published in part, Bellarium rotundum Anikeeva, Sergeeva et Gooday, 2013, Allogromiid sp. 40, Allogromiid sp. 42 (Sergeeva, Anikeeva, 2018), Allogromiid sp. X, Allogromiid sp. W and Allogromiid sp. Z (unpublished data) inhabit Sivash. Bellarium rotundum and Allogromiid sp. 42 have been found in the Sea of Azov and Sivash Bay at a salinity of no more than $10 \%$, Allogromiid sp. 40 has only been recorded in Sivash at a salinity of up to $40 \%$ o but other monothalamid species appear to be resistant to the high salinity of Sivash.

Vellaria pellucida and V. sacculus were previously recorded in the Sea of Azov in habitats with a salinity of $14 \%$ (Sergeeva, 2016), but these species have not been found in Sivash. The new species Vellaria solenta inhabits Sivash Bay at salinity of up to $74 \%$. How this species 
Table 1. Morphological parameters of the holotype (in $\mu \mathrm{m})$, the three paratypes and other examined specimens of Vellaria solenta.

Таблица 1. Морфологические параметры голотипа (в мкм), трёх паратипов и других исследованных особей Vellaria solenta.

\begin{tabular}{|l|c|c|c|c|c|}
\hline \multicolumn{1}{|c|}{ Specimen } & $\begin{array}{c}\text { Test } \\
\text { length }\end{array}$ & $\begin{array}{c}\text { Test } \\
\text { width }\end{array}$ & $\begin{array}{c}\text { Diameter of } \\
\text { apertural neck }\end{array}$ & Nucleus & $\begin{array}{c}\text { Coefficient } \\
\boldsymbol{C}\end{array}$ \\
\hline Holotype & 310 & 70 & 25 & 18 & 4.4 \\
\hline Paratype 1 & 330 & 75 & 26 & 18 & 4.4 \\
\hline Paratype 2 & 365 & 75 & 25 & 15 & 4.8 \\
\hline Paratype 3 & 350 & 50 & 20 & - & 7 \\
\hline Specimen No. 1 & 365 & 80 & 23 & - & 4.5 \\
\hline Specimen No. 2 & 320 & 90 & 18 & - & 3.5 \\
\hline Specimen No. 3 & 410 & 70 & 26 & 21 & 5.8 \\
\hline Specimen No. 4 & 350 & 65 & 20 & 28 & 5.4 \\
\hline Specimen No. 6 & 300 & 50 & 18 & - & 6 \\
\hline Specimen No. 8 & 380 & 70 & 20 & - & 5 \\
\hline Specimen No. 9 & 435 & 70 & 10 & 20 & 6.2 \\
\hline Specimen No. 10 & 300 & 70 & 20 & - & 4.3 \\
\hline Specimen No. 11 & 240 & 70 & 20 & - & 3.4 \\
\hline Specimen No. 13 & 240 & 50 & 18 & 15 & 4.8 \\
\hline Specimen No. 14 & 270 & 60 & 13 & 16 & 4.5 \\
\hline Specimen No. 16 & 350 & 60 & 26 & - & 5.8 \\
\hline
\end{tabular}

"_" = not visible.

penetrated into these hypersaline conditions is unknown. We assume that it has long inhabited the harsh environment of Sivash, but since softwalled foraminifers have never been investigated in this area, we cannot say for sure. It is unlikely that they come from the adjacent, brackish waters of the Sea of Azov.

Acknowledgements. The authors are grateful to colleagues from the IBSS Dr. E.V. Anufrieva and Dr. N.V. Shadrin for providing the samples of bottom sediments for the analysis of soft-walled foraminifers. We are deeply appreciative to Professor Andrew Gooday of the National Oceanography Centre, Southampton, UK, for his help in editing the English text of the manuscript. We are also thankful to colleagues Dr. V.A. Timofeev and PhD T.N. Revkova for their help in the preparation of the illustrations.

This work has been carried out within the framework of the IBSS RAS themes: "Basic research of population biology of sea animals, their morphological and genetic diversity" (No.
reg.AAAA-A19-119060690014-5) and "Regularities of formation and anthropogenic transformation of biodiversity and bioresources of the Azov-Black Sea basin and other areas of the World Ocean" (No. reg. 1210301000280 ). This study was also partially funded by the RFBR and the Government of Sevastopol (research project state registration number 18-44920024).

\section{References}

Anikeeva O.V. 2007. [Taxonomical composition and seasonal dynamic of the soft-shelled foraminifera in the Sevastopol Bay (the Black Sea)] // Ekologiya Morya. Vol.74. P.5-9 [in Russian].

Anikeeva O.V., Gooday A.J. 2016. Taxonomic composition and distribution of soft-walled monothalamid foraminifera in the area of Zernov's Phyllophora Field (NW Black Sea) // Mar. Biol. Res. Vol.12. No.6. P.640-646.

Dovgal I.V. 2005. [Nature of Sivash region and human impact on it (state of study and bibliography)] // Dovgal I.V., Kostyushin V.A. (eds.). Aquatic invertebrates, Chapter 4.1. Kiev. P.20-23 [in Russian, with English summary]. 
Gooday A.J., Fernando O.J. 1992. A new allogromiid genus (Rhizopoda: Foraminiferida) from the Vellar Estuary, Bay of Bengal // J. Micropalaeontol. Vol.11. No.2. P.233-239.

Gooday A.J., Anikeeva O.V., Pawlowski J. 2011. New genera and species of monothalamous foraminifera from Balaclava and Kazach'ya Bays (Crimean Peninsula, the Black Sea) // Mar. Biodiv. Vol.41. No.4. P.481-494.

Hayward B.W., Le Coze F., Vachard D., Gross O. 2021. World Foraminifera Database. Vellaria Gooday \& Fernando, 1992. Accessed through: World Register of Marine Species at: http://marinespecies.org/aphia. php? $\mathrm{p}=$ taxdetails\&id=390799 on 2021-02-28

[Report of the Collegium No.2: State Committee for Water Management and Land Reclamation of the Republic of Crimea.] 7 April 2015. 14p.

Sabbatini A., Pawlowski J., Gooday A.J., Piraino S., Bowser S.S., Morigi C., Negri A. 2004. Vellaria zucchellii sp. nov. a new monothalamous foraminifer from Terra Nova Bay, Antarctica // Antarctic Science. Vol.16. No.3. P.307-312.

Shadrin N.V., Anufriieva E.V., Kipriyanova L.M., Kolesnikova E.A., Latushkin A.A., Romanov R.E., Sergeeva N.G. 2018. The political decision caused the drastic ecosystem shift of the Sivash Bay (the Sea of Azov) // Quaternary International. Vol.475. P.4-10.

Sergeeva N.G. 2016. [Soft-walled benthic Foraminifera of the Black Sea and Azov Sea] // A.V. Gaevskaya (ed.). Sbornik materialov Vserossiyskoi nauchno-prakticheskoi konferentsii "Morskie biologicheskie issledovaniya: dostizheniya i perspektivy". Sevastopol. Vol.2. P.141-145 [in Russian, with English summary].

Sergeeva N.G., Anikeeva O.V. 2004. New Black Sea foraminifera from the Allogromiidae family // 4th International Congress "Environmental Micropaleontology, Microbiology and Meiobenthology". Isparta, Turkey. P.179-180.

Sergeeva N.G., Anikeeva O.V. 2018. [Soft-shelled foraminifera of the Black Sea and the Sea of Azov]. Simferopol: PP “ARIAL”. 156 p. [In Russian, with English summary]

Sergeeva N.G., Shadrin N.V., Anufriieva E.V. 2019. Longterm changes (1979-2015) in the nematode fauna in Sivash Bay (Sea of Azov), Russia, worldwide the largest hypersaline lagoon, during salinity transformations // Nematology. Vol.21. No.4. P.337-347.
Sergeeva N.G., Shadrin N.V., Abibulaeva A.Sh., Dovgal I.V. 2020. Records of sessile ciliates (Ciliophora, Peritrichia) on the green filamentous algae Cladophora sivashensis in the Sivash Bay (the Sea of Azov) // Protistology. Vol.14. No.2. P.89-94. DOI: 10.21685/ 1680-0826-2020-14-1-6

Shadrin N.V., Anufriieva E.V., Kipriyanova L.M., Kolesnikova E.A., Latushkin A.A., Romanov R.E., Sergeeva N.G. 2018. The political decision caused the drastic ecosystem shift of the Sivash Bay (the Sea of Azov) // Quaternary International. Vol.475. P.4-10.

Shadrin N.V., Kolesnikova E.A., Revkova T.N., Latushkin A.A., Chepyzhenko A.A., Dyakov N.N., Anufriieva E.V. 2019. Macrostructure of benthos along a salinity gradient: The case of Sivash Bay (the Sea of Azov), the largest hypersaline lagoon worldwide // J. Sea Res. Vol.154. P.101811.

Shadrin N.V., Sergeeva N.G., Latushkin A.A., Kolesnikova E.A., Kipriyanova L.M., Anufrieva E.V., Chepyzhenko A.A. 2016. [Transformation of Sivash Bay (the Sea of Azov) under increasing salinity: changes in meiobenthos and other ecosystem components (20132015)] // J. Siberian Federal University. Ser.: Biology. Vol.9. No.4. P.452-466 [in Russian].

Shchurova E.S., Sovga E.E., Khmara T.V., Lomakin P.D. 2016. [Changes in the resource potential of Sivash Bay (the Sea of Azov) after the closure of the NorthCrimean Channel in 2014] // Ecologiya. Economika. Informatika. Azovskoe more, Kerchenkiy proliv i predprolivnye zony v Chernom more: problemy upravleniya pribrezhnymi territoriyami dlya obespecheniya ekologicheskoi bezopasnosti i ratsional'nogo prirodopol'zovaniya: Materialy III Vserossiyskoi konferentsii. Rostov-on-Don: SFU Publishing House. P.296-307 [in Russian].

Sovga E.E., Eremina E.S., Dyakov N.N. 2018a. [System of the ecological monitoring in the Sivash Bay in the modern conditions.] // Ecological safety of coastal and shelf sea zones. Vol.2. P.22-38. doi:10.22449/24135577-2018-2-22-38

Sovga E.E., Eremina E.S., Khmara T.V. 2018b. [Water balance in the Sivash Bay as a result of variability of the natural-climatic and anthropogenic factors] // Morskoy Gidrophizicheskiy Zhurnal. Vol.34. No.1. P.71-81. doi:10.22449/0233-7584-2018-1-71-81

Responsible editors A.V. Chernyshev, E.N. Temereva 